\title{
Toward a Transformative Social Protection: A Gender Analysis of Funeral Insurance in the Wa West District of Ghana
}

\author{
John Oti Amoah
}

Community-initiated funeral insurance plays a critical role in the well-being of many people in sub-Saharan-Africa; yet, mainstream social protection programs tend to focus on cash transfer interventions. I argue that funeral insurance and gender need to be at the core of the strategies to understand social protection. I explore findings from a qualitative study of beneficiaries' experiences of funeral insurance group in the Wa West District of Ghana. Narratives suggest that participation in funeral insurance groups improve the well-being of women. Efforts should be directed toward scaling up funeral insurance groups in developing countries due to the social significance of funerals.

Keywords: gender, funeral insurance, self-help groups, social protection, social transformation, Ghana

\section{Introduction}

Presently, an estimated 1.9 billion people in the world receive social safety net programs in the form of conditional or unconditional cash transfers, nutritional feeding programs, public works programs, and fee waivers (Devereux \& Solórzano, 2016). Similarly, almost every country in the world has at least one social safety net program in place. However, these social protection programs cover only onethird of the world's poor (Honorati, Gentilini, \& Yemtsov, 2015).

John Oti Amoah is a Research Fellow at the Centre for Gender Research, Advocacy and Documentation, University of Cape Coast, Ghana. He holds a PhD from the University of Cape Coast, Ghana. He previously held a Postdoctoral Fellow position at the International Center for Development and Decent Work, University of Kassel, Germany. His current research centers around gender, livelihoods, social protection, as well as development alternatives. He can be contacted at jotiamoah@gmail.com 
Globally, every society has its norms and practices regarding burial rites and reverence for the dead. Funerals entail financial, psychological, as well as social resources. Funerals are costly in Africa due to their social importance (De Witte, 2003). Case, Garrib, Menendez, and Olgiati (2013) argued that the importance of funeral ceremonies in Africa is relatively higher than other life cycle events such as births and marriages in community life. Jindra and Noret (2011) has noted that in Africa, burial rites connote more importance than they do in the global North. In Ghana, for instance, De Witte (2003) observed that a grand funeral signifies a person's financial or social contribution to his or her matrilineal kinship group. Moreover, the funeral is the main event through which the family can gain prestige and show off wealth in a struggle for status. The social importance and the financial implications of funeral rites explain the widespread existence of funeral insurance and associations in sub-Saharan Africa.

Faced with widespread mortality, due to Ebola, HIV/AIDS, and the COVID-19 pandemic, which massacred huge numbers of working adults leaving behind many orphans without carers, the role of funeral insurance is important in the social protection discourse, not just for tackling financial vulnerabilities associated with funeral rites but also in promoting broader social inclusion. Funeral insurance is to cover the cost of a funeral in the event of the death of a member or dependent of a member (Berg, 2011; Dercon, De Weerdt, Bold, \& Pankhurst, 2006; Lemay-Boucher, 2012). That is, it offers a vehicle for the management of the risk of insufficient financial and social support for funerals rites.

Funeral insurance is among the oldest forms of social protection in many developing economies (Berg, 2011). In spite of its existence for decades in many developing countries, community-based funeral insurance has been understudied. Earlier studies on funeral insurance groups primarily focused on their functioning and scope of insurance coverage from an economic perspective (Dercon et al., 2006; Lemay-Boucher, 2012). This article is different in the sense that it shifts attention to the gender dynamics of membership as well as the nonfinancial component of indigenous funeral insurance package. I situate this paper within the framework of alternatives for social transformation beyond most existing social protection systems that are institutionally structured around formal employment and a hegemonic ideal of a good life under capitalist conditions. It also implies providing space to other forms of understanding social protection beyond the language of economics.

This paper contributes to the debates on social protection by showing that in addition to financial packages given to beneficiaries, funeral insurance can also have positive relational as well as transformational gender effects on the lives of people. To situate the findings within the debates, Section 2 presents arguments that conceptualize the interplay between social protection and social transformation. Section 3 reviews the funeral insurance discourse. Section 4 provides the qualitative research methodology underpinning the study. Section 5 discusses the findings regarding the membership base of funeral insurance from a gender 
point of view and participation outcomes. The article ends with a discussion on the elements of social transformation in funeral insurance groups.

\section{Conceptual Issues}

There are many definitions of social protection reflecting the agendas of agencies and academics. Most definitions of social protection address protection against vulnerability, risk, and unacceptable levels of deprivation through responses, which are both formal and informal (Norton, Canway, \& Foster, 2001; Palmer, 2013). Nonetheless, the social protection discourse is divided, not only on design questions such as choices in the intervention design (universal, targeting provision, and unconditional and conditional transfers) but also more fundamentally on competing for theoretical explanations of the nature of vulnerability constraints. These contestations have produced a range of approaches to social protection in development planning and practice.

Munro (2008) traced the origin of social protection from competing development perspectives underscoring the role of needs, risks, and rights. The International Labour Organization (ILO) determines the basis of social protection in citizen-rights-based perspective to human development. In this context, social protection programs comprise the progressive realization of particular rights such as the right to social security in the Declaration of Human Rights. White (2010) and others found a theoretical grounding in the satisfaction of basic needs. Here, social protection interventions are justified by society's obligation to ensure basic levels of need satisfaction (White, 2010). Yet, the Bretton Woods Institutions locate it in the context of lifting the constraints to human and economic development posed by social risk (Barrientos \& Hulme, 2009).

The transformative social protection framework designed by Devereux and Sabates-Wheeler (2004), on the contrary, weave together the concepts of human rights, needs, and empowerment to produce a comprehensive framework. The transformative social protection framework seeks to achieve social justice, and its view suggests that in addition to addressing economic needs, social protection must empower the poor and support their rights. They consider extreme poverty, vulnerability, and inequality as indicators of structural inequity and social injustice. Rooted firmly in the transformative social protection discourse is gender.

It could be argued that the introduction of the gender dimension in the conceptualization of vulnerability and social protection has shifted the discourse from masculine-based social protection interventions toward what is known as transformative social protection interventions, which are still in the early stages of research (Holmes \& Jones, 2011; Saxonberg, 2012). Bachelet (2012) proposed that social protection can contribute to gender empowerment and social cohesion. Specifically, a well-coordinated package of social protection interventions that improve women's skills and well-being; reduce unpaid care work; and increase their access and control of resources, not only promotes women's economic empowerment but also helps to effectively and sustainably reduce rural poverty 
and gendered vulnerability (Devereux \& Sabates-Wheeler, 2007; Holmes \& Jones, 2013). Given that those who need protection from risk-prone conditions the most are rarely part of program design and implementation, a gender approach may see social protection that leads to social justice.

This article's point of departure is drawing on new theoretical views of social transformation. Following Lang and Hoetmer (2018), the conceptual framework of this study is organized on five dimensions of transformation. The first dimension looks at overcoming patriarchal gender relations. This dimension involves all forms of sexual division of labor as well as representation and decision-making processes. The second dimension looks at the enhancement of democracy. Democracy here is conceptualized as continuing, open-ended collective process of decision-making. The third dimension entails the introduction of more equitable social relations, including the capacity to culturally share inequalities and vulnerabilities to undermine hegemonic forces. With the generation of specific contextual knowledge and experience not limited to Eurocentric knowledge as its focus, the fourth dimension is to initiate social transformation. The fifth dimension, finally, refers to overcoming commonization or de-commodification of some aspects of life such as death. This implies liberating people from the hegemonic ideal of market profit logics to reproduce life in dignity and symbolic dimensions.

\section{Social Insurance and Funeral Insurance}

Social insurance as a social protection instrument is based on the insurance principle. Social insurance interventions are contributory programs that protect beneficiaries from disastrous expenses in exchange for regular payments of premiums (Lund, 2009). It can also be conceptualized as a large number of individuals or households that have equal social protection needs combining to mitigate risks by pooling their contributions in a common fund which can then provide predefined benefits to members in the event of specified occurrences (Norton et al., 2001). Social insurance schemes include unemployment insurance, pension scheme, and health and crop insurance. Formal insurance schemes are more extended in the developed world where people can more easily contribute, with a high percentage of the labor force belonging to the formal sector of the economy. However, in most developing countries, a high rate of the labor force operates outside the formal sector, which makes it difficult to run an insurance-based on Western models.

In a formal economy, social insurance responds to labor market threats, such as unemployment, old age, illness, and death, through transfer payments that are financed from the contributions made by employers and employees. In many developing countries, coverage has tended to be low given the large size of the informal economy, and the high rate of evasion of contributions, even by employers and employees in the formal sector (Razavi, 2011).

Funeral associations are among the insurance providers for people in the informal economy. The operations of funeral associations are underpinned by a clearly defined set of rules, detailed terms and conditions including fines for 
noncompliance, amount of premium, beneficiaries, and payout (Berg, 2017; Dercon et al., 2006; Lemay-Boucher, 2012). However, most funeral associations are considered to be informal because they are not registered with the state. The history of funeral insurance is connected to activities of funeral associations. According to Berg (2017), funeral insurance extends its roots from sub-Saharan Africa through medieval Europe to ancient Greece and Rome, whereby the easiest way to insure against funeral expenses has been to join a funeral association. The principal function of these associations is to pool the risk associated with the death of members or their close relatives by using members' contributions to organize funerals. Historians have maintained that funeral associations are the antecedents of modern insurance companies (Trenerry, 2009).

Dercon et al. (2006) pointed out that funeral insurance groups in Ethiopia and Tanzania have features of inclusiveness. They discuss the history and functioning of funeral insurance from an economic standpoint. Lemay-Boucher (2012) used survey data from Benin to observe that funeral insurance group participation is gender-neutral in Cotonou and that the decision to join such a funeral association is made individually within a household. In all these contexts, the funeral associations are well structured with clear rules and regulations. Berg (2011) discussed funeral insurance in the context of South Africa as a unique life insurance bundled with a restraint on how the payout is spent. Case et al. (2013) observed that households that get a funeral insurance payout at the time of a bereavement spent more on the funeral. This article departs from these economics-related literatures by using qualitative methods to unpack the gender dynamics of membership as well as the nonfinancial component of funeral insurance.

\section{Methodology}

Methodologically, I would like to supplement economic quantitative discourse on funeral insurance with qualitative analysis of agency and subjective experiences. The Wa West District is completely rural and has the highest poverty headcount (92.4\%) in the Upper West Region of Ghana (Ghana Statistical Service, 2015). In the district, the study was conducted in the Dorimon community. The study population comprised female and male farmers in the Wa West District. Homogeneous purposive sampling was used to select the farmers (women and men). The participants were aged between 20 and 65 years, and most had not received any formal education. The data collection happened in July 2017. The data-gathering techniques used in this study were interviewing and focus group discussions (FGDs). In-depth interviews with the leader as well as some participants were conducted in Wali, a widely spoken local language of the people. Four FGDs were organized for participants and nonparticipants of the funeral insurance group. The discussions were conducted separately with women and men. Although the FGD guide was written in the English Language, interviews were conducted in Wali. FGDs were held with between 8 and 10 participants. The collected data were subjected to axial coding based on the conceptual framework presented earlier. 
Triangulating the findings from the FGDs with different respondents from the same interest group increased the trustworthiness of the results.

\section{Description of Funeral Insurance}

In the Dorimon community, the funeral insurance fund was referred to as Nouriyeni, which literally means "one mouth." According to the members, the fund was aimed at mitigating the pressure on their husbands to foot the funeral expenses of their parents-in-law. The members of the funeral insurance group noted that the decision to join the group was associated with the shame that they faced as women when their husbands were unable to foot the bill of their parents-in-laws' funeral expenses.

The funeral insurance group members were self-selected and self-governed. According to the participants, the leader of the group at the time of the data gathering was unanimously selected because she was a unifier. Members said that given her integrity, she has been appointed as the new queen mother of the Dorimon community. According to the group members, the community was zoned into three-Budayiri, Nayiri, and Zongo - to facilitate the smooth collection of members' contributions to the fund. Members pay an agreed weekly premium fee of GH\& 1 (US\$ 0.17) toward the fund. The leader of the fund explained that new community members who chose to join the group were charged GH 450 (US\$ 8.63 ) as a subscription fee. However, community members who decide to join the group rather at a later date in their life were only admitted to the group upon paying a higher commitment fee of GH 200 (US\$ 34.51). Participants reported that they received a lump sum of GH 1000 (US\$172.55) on the death of the insured parents. Members, however, pointed out that defaulters were not given the full financial benefit. Members who had already lost their insured parents and are in good standing were partially compensated when they lose a child. The accounting principle of cash inflow and outflow underpinned premiums and payouts to members. The group holds regular meetings, and it is obligatory for members to attend.

\section{Results and Discussion}

\section{Gender Dynamics of Participation}

Participants reported that Nouriyeni is a female-only insurance fund. Although the members reported that the group was a female-only group, probing revealed that the organizer of the group was a 60-year old man. When asked why he was accepted to be part of the group, the members of the group explained that he is a unifier and a women's advocate. Members further described his role in disputes resolution during group meetings. For example, the 58-year old leader of the group had this to say:

Where two or more women are gathered, disagreements are bound to happen. However, with Nasara [nickname], being an elderly man and unifier, such disagreements are resolved amicably. 
When asked about the exclusion of other men from the group, the participants explained that men are domineering in all spaces. The 58-year old leader of the group had this to say:

"Dorimon" men are very arrogant and bossy in all decision-making. They will not allow us to say a word in our meetings if we should include them. We know them. Moreover, even if we should bring them on board, they will not pay the weekly contributions or stay throughout the meetings with the excuse that they have other engagements. We do not want their wahala [trouble]. We have a united front as women towards any goal, unlike the men.

When the men were asked as to why they were not members of the funeral insurance groups, they explained that it was difficult to work with their fellow men in groups, especially when it had to do with monetary issues. The male nonmembers of funeral insurance groups cited reasons such as stiff competition for leadership positions and unnecessary oppositions on issues that call for mutual efforts as significant limitations toward the formation of or joining an insurance group. This is inconsistent with Lemay-Boucher's (2012) findings that funeral insurance group participation is gender-neutral. Contrary to Dercon et al. (2006), the findings on the gender dynamics of this study suggest that membership is not inclusive as men have a limited chance to participate in funeral insurance groups.

Responses from the participants suggest that the funeral insurance group has been in existence for over three decades, as they noted that their aged and deceased mothers were members of the group. Participants highlighted that the group is exclusively for supporting funeral expenses.

Thus, funeral insurance aimed at averting deprivation and social vulnerabilities associated with social exclusion and funeral expenses. The presence of funeral insurance group in the study site gives credibility to the observation by Entz, Karsgaard, and Salomons (2016) that community-based savings and insurance groups were observed as early as the late 19th century in West African countries as well as in Asian countries (India and China).

\section{Participation Outcomes from Funeral Insurance}

In exploring the effects of the funeral insurance (Nouriyeni), the study asked about the material and social changes in the lives of participants in terms of expenditure capacities and relational outcomes. In the examination of the material effects, participation in the funeral insurance association (Nouriyeni) according to the members enabled them to mitigate the socioeconomic vulnerability associated with funeral expenses. Participants explained that the financial package of $\mathrm{GH} \phi$ 1000 (US\$ 172.55) paid out to beneficiaries help in covering funeral bills. Interviews with the nonparticipants of the community-managed funeral insurance fund suggest that they did not receive large funeral donations compared to their colleagues who were members of the community-managed funeral insurance fund. The nonmembers of the insurance group claimed they received pittance as 
funeral donations from sympathizers. A 35-year old female nonparticipant of the funeral insurance group had this to say:

I received gifts from my friends and other community members when I lost my mother. Well, because I am yet to join the Nouriyeni [Funeral Insurance Group], I did not receive their lump sum of $\mathrm{GH} \phi 1,000$. I have not been a member because I was away for some time. I think it is an excellent group to join.

In the interviews, the funeral insurance group participants noted that they occasionally receive pittance as compensation for other family relations that were not covered by the funeral insurance fund. A 41-year old member during the FGDs narrated a situation in which she was compensated for the death of her child:

When I lost my son last year, members of the funeral insurance group made a monetary donation when they visited me. I was impressed with their contribution.

The findings on the funeral insurance group activities showed that the funeral financial package increases a household's capacity to face recurrent shocks related to funeral rites and expenses.

\section{Relational Outcomes}

Relational outcomes reveal changes in social interaction. Participants were asked to outline the types of decisions made at the household level. The female FGD participants of the funeral insurance group indicated that reproductive roles such as cooking, laundry, childcare were within their purview. They noted that men made decisions on production activities. Some participants reported that household expenditure decisions were jointly made by husbands and wives. However, they expressed that men had the final word. Other dissenting views explained that household expenditure decisions were the sole responsibility of men. When asked whether participation in funeral insurance groups have resulted in a change in household decision dynamics, the results showed that men still exercise complete control over the household production decision-making process:

My participation in the Nouriyeni have not brought any change in the house decision-making process. My husband has the final say in all farming-related activities such as what to cultivate and the type of input to be purchased. [FGD, Female Farmers, Dorimon]

The female FGD participants noted that their husbands have the final say in all issues within their households. This finding is inconsistent with Entz et al.'s (2016) claim that increased decision-making in the household is a common outcome of women's participation in savings and financial groups. 
Participation in community funeral insurance provides mutual support during social events such as birth rites, marriages, and funeral ceremonies. The assistance rendered to participants included physical labor during the funeral ceremony. A 23-year old female member of the community funeral insurance group had this to say:

My sisters [members] consoled me during the death of my mother. They helped with the cooking of meals for the burial ceremony. This is a bigger family with love and solidarity.

Members reported that participation in the funeral insurance group provides psychological and emotional support for the bereaved members of the group. This positive effect notwithstanding, funeral insurance participants maintained that their primary challenge was their inability to contribute regularly. They attributed this to many constraints they face in their livelihood activities. When the beneficiaries were asked to describe their challenges, the responses pointed to one direction: the fine of 50 Pesewas for late attendance to meetings is our main difficulty. They maintained that the lateness to the weekly meeting was because of their heavy domestic roles.

Regarding the patriarchal gender relations dimension, the community funeral insurance has challenged the established decision-making in the Dorimon community. Women in leadership positions at the funeral insurance group as well as community governance have introduced structural and symbolic processes of deconstructing patriarchy. However, decision-making dynamics at the household level maintains the patriarchal order. With respect to enhancement of democracy, the funeral insurance group demonstrated an open collective process of sharing and distributing power. Regarding the de-commodification dimension of transformation, funeral insurance departs from the profit logic deeply expressed in the Western-based funeral insurance. In this way, the community funeral insurance has opened space to ensure collective and community-based management. The funeral insurance is managed collectively for the social and material benefit of all members. For equitable social relations, funeral insurance in the study context has reduced vulnerabilities associated with funeral expenses. The unique experiences of the operations and practices of the community funeral insurance have generated decolonized knowledge, which can form a basis for enhancing community-led social protection structures. Beyond these dimensions of social transformation, the article explored research questions that orient the way research participants described their experiences.

\section{Conclusions}

Membership acceptance is underpinned by gender. The funeral insurance group (Nouriyeni) offered participants resilience to vulnerability associated with the funeral cost. Participation in funeral insurance group has not resulted in a change in household decision-making dynamics. The study observed that men still 
exercise complete control over the decision-making process concerning household production. Analysis revealed that community-managed funeral insurance fund increased social solidarity among members over issues that concerned them. From the analysis, it can be concluded that the funeral insurance is an integral part of the social transformation system of Wa West District welfare mix. The sustainability of the community-managed funeral insurance group (Nouriyeni) is clearer, with the reports confirming that groups continue offering financial services as well as emotional support following the exit of founding agents.

\section{Acknowledgements}

The author is grateful to the International Center for Development and Decent Work for his postdoctoral fellowship.

\section{References}

Bachelet, M. (2012). Social protection floor for a fair and inclusive globalization. Geneva: International Labour Office.

Barrientos, A., \& Hulme, D. (2009). Social protection for the poor and poorest in developing countries: Reflections on a quiet revolution. Oxford Development Studies, 37(4), 439-456. doi:10.1080/13600810903305257

Berg, E. (2017). Funeral insurance: An inter-generational commitment device? Journal of African Economies, 27(3), 321-346. doi:10.1093/jae/ejx037

Berg, E. (2011). Funeral insurance. Centre for the Study of African Economies. Case, A., Garrib, A., Menendez, A., \& Olgiati, A. (2013). Paying the piper: The high cost of funerals in South Africa. Economic Development and Cultural Change, 62(1), 1-20. doi:10.1086/671712

Dercon, S., De Weerdt, J., Bold, T., \& Pankhurst, A. (2006). Group-based funeral insurance in Ethiopia and Tanzania. World Development, 34(4), 685-703. doi:10.1016/j.worlddev.2005.09.009

Devereux, S., \& Sabates-Wheeler, R. (2004). Transformative social protection (Working Paper No. 232). Brighton, England: Institute of Development Studies.

Devereux, S., \& Sabates-Wheeler, R. (2007). Editorial introduction: Debating social protection, IDS Bulletin 38(3). Brighton, England: Institute of Development Studies.

Devereux, S., \& Solórzano, A. (2016). Broadening social protection thinking. In A. Aghajanian, \& J. Allouche (Eds.), Development studies: Past, present and future (pp. 63-76). Sussex: Institute of Development Studies.

De Witte, M. (2003). Money and death: Funeral business in Asante, Ghana. Africa: Journal of the International African Institute, 73(4), 531-559. doi:10.3366/ afr.2003.73.4.531

Entz, M., Karsgaard, J., \& Salomons, M. (2016). An overview of savings and self-help groups, their contributions to improved food security, and how to improve their function: A literature review. Toronto: Canadian Foodgrain Bank. 
Ghana Statistical Service. (2015). Ghana poverty mapping report. Accra: GSS Publication.

Holmes, R., \& Jones, N. (2011). Gender inequality, risk and vulnerabilty in rural economy: Refocusing the public work agenda to take account of economic and social risks (ESA Working Paper No. 11-13). Rome, Italy: FAO Publications.

Holmes, R., \& Jones, N. (2013). Gender and social protection in the developing world: Beyond mothers and safety nets. London: Zed Books.

Honorati, M., Gentilini, U., \& Yemtsov, R. G. (2015). The state of social safety nets. Washington, DC: World Bank.

Jindra, M., \& Noret, J. (Eds.). (2011). Funerals in Africa: Explorations of a social phenomenon. Berghahn Books.Lang, M., \& Hoetmer, R. (2018). Seeking alternatives beyond development. In M. Lang, C. D. Konig, \& A. C. Regelmann (Eds.), Alternatives in a world of crisis (pp. 3-15). Brussels: Universidad Andina Simon Bolivar.

Lemay-Boucher, P. (2012). Insurance for the poor: The case of informal insurance groups in Benin. Journal of Development Studies, 48(9), 1258-1273. doi:10.1 080/00220388.2012.693172

Lund, F. (2009). Social protection and the informal economy: Linkages and good practices for poverty reduction and empowerment. Paris, France: SEWA and StreetNet.

Munro, L. T. (2008). Risks, rights and needs: Compatible or contradictory bases for social protection. In A. Barrientos \& D. Hulme (Eds.), Social protection for the poor and poorest: Concepts, policies and politics (pp. 27-46). London: Palgrave Macmillan.

Norton, A., Conway, T., \& Foster, M. (2001). Social protection concepts and approaches: Implications for policy and practice in international development (ODI Working Papers No. 143). London, England: ODI Publications.

Palmer, M. (2013). Social protection and disability: A call for action. Oxford Development Studies, 41(2), 139-154. doi:10.1080/13600818.2012.746295

Razavi, S. (2011). Engendering social security and protection: Challenges for making social security and protection gender equitable. International Association for Feminist Economics (IAFFE). Hangzhou: Global Policy and Development Department.

Saxonberg, S. (2012). From defamilialization to degenderization: Toward a new welfare typology. Oxford: Blackwell Publishing Limited.

Trenerry, C. F. (1926). The origin and early history of insurance: Including the contract of Bottomry. London: P. S. King \& Son.

White, S. (2010). Ethics. In F. G. Castles, S. Leibfried, \& J. Lewis (Eds.), The Oxford handbook of the welfare state (pp. 19-31). Oxford: Oxford University Press. 